\title{
Conservation of the Tropical Rainforest in the Usumacinta Canyon Flora and Fauna Protection Area in Mexico
}

\author{
Palomeque-De la Cruz, Miguel Ángel ${ }^{1}$; Ruiz-Acosta, Silvia del Carmen ${ }^{2}$; Sánchez, Alberto J; \\ Ramos-Reyes, Rodimiro ${ }^{3}$; Galindo-Alcántara, Adalberto ${ }^{1}$
}

\begin{abstract}
1Universidad Juárez Autónoma de Tabasco. División Académica de Ciencias Biológicas. Villahermosa, Tabasco, México. ${ }^{2}$ Tecnológico Nacional de México. Instituto Tecnológico de la Zona Olmeca, Ocuiltzapotlán, Tabasco, México. ${ }^{3} E$ E Colegio de la Frontera Sur Campus Villahermosa. Ranchería Guineo 2da Sección, Tabasco, México.
\end{abstract}

*Corresponding author: aga2003a@hotmail.com

\begin{abstract}
Objective: To study the conservation status of the tropical rainforest in the "Cañón del Usumacinta" Flora and Fauna Protection Area in Mexico, through an analysis of the change in land use and vegetation (1997, 2009 and 2016).

Design/Methodology/Approach: Vegetation and land use shapefiles at 1:250,000 scale (national continuum) corresponding to 1997 (series I), 2009 (series IV), and 2016 (series VI) were downloaded. Finally, a spatial analysis was generated with calculation of exchange rates, using the Land Change Modeler between 1997-2009 and 2009-2016.

Results: During 1997-2009, the tropical rainforest occupied 31.2\% and the greatest impact of the period seen was a change rate of $7.4 \%$. Subsequently, between 2009 and 2016 there was a great decrease in the land use change rate in the forest $(0.8 \%)$, due to its decree as a federal Protected Area in 2008, as well as natural regeneration and the promotion of ecological restoration programs.
\end{abstract}

Study Limitations/Implications: Absence of geographic variables to analyze factors driving change in land use.

Conclusions: It is essential to promote the sustainable management of the Usumacinta Canyon based on what is established in the land use planning program and the management plan, and to redouble efforts to implement actions for restoring ecosystem services and the continuous monitoring of change in land use.

Keywords: Biological conservation; Protected areas; High Evergreen Forest; Territorial Ecological Planning.

\section{INTRODUCTION}

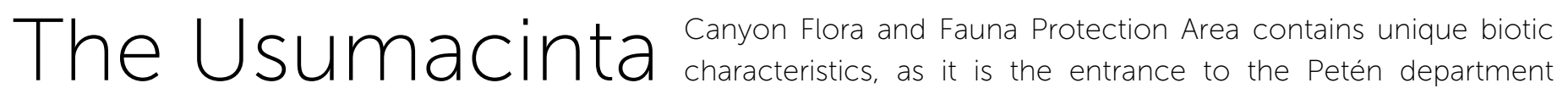
of Guatemala and to the Mesoamerican Biological Corridor, which spans from Mexico to Central America and constitutes the second most extensive mass of tropical rainforest after the Amazon (Arriaga et al., 2000; DOF, 2008: 
Mifsut and Castro, 2010; Hernández-López et al., 2013, Mercedes Castillo, Barba-Álvarez, and Mayorga, 2018). One of its most characteristic traits is the presence of high evergreen rainforest, which is the most exuberant vegetation as well as the richest and most diverse of all the plant groups, according to Rzedowski and Huerta (1994). The most representative species of the reserve are chicozapote (Manilkara zapota), zapote (Pouteria sapota), breadnut (Brosimum alicastrum), guapaqué (Dialium guianense), and canxán (Terminalia amazonia) (Figure 1; DOF, 2008).

Until the 1960s, accessibility conditions kept the Usumacinta region practically unpopulated, registering during this period the establishment of the first population nuclei, with anthropic activities and devastating practices for the region's rainforest (Isaac-Márquez et al., 2005; García and Soares, 2017). In this same decade, ecosystems in the Usumacinta and Chontalpa regions turned out to be the most impacted in the following watersheds: the Grijalva-Usumacinta due to the start of plans for directed colonization and productive modernization; the Chontalpa and Balancan-Tenosique, which influenced the dynamics of the population and territory (Isaac-Márquez et al., 2005; Zavala and Castillo 2007; García-Morales et al., 2014). identify ecosystems in good state of conversion, as part of a strategy to mitigate the impact of the productive activities of the Chontalpa Plan and the BalancánTenosique Plan (SEMARNAT, 2015). It wasn't until 2005 that the Official Journal of the state published the Protected Area decree with state jurisdiction, designated as the Usumacinta Canyon State Park (Periódico Oficial del estado de Tabasco, 2005). Three years after the state decree, the federation released a decree that included the Usumacinta Canyon within the category of Flora and Fauna Protection Area (DOF, 2008).

In the Usumacinta Canyon, there are still important high evergreen rainforest areas in corridors and fragments, but their full extent and current state of conservation are unknown. This information is essential to support ecological land use planning (VelascoTapia, 2010). Thus, Balvarena (2012) and JiménezSierra et al. (2014) consider it necessary to study the dynamics of high evergreen rainforest covers due to the influence that they have on the presence or decrease of ecosystem services like climate regulation, carbon storage, water regulation (increase in infiltration and evapotranspiration), water quality, erosion, landslides, and flood control, among others.
By 1970, the high evergreen rainforest represented $81.3 \%$ of the Usumacinta Canyon (Palomeque-de la Cruz, 2008). However, the livestock farming conversion process that was initiated in the previous decade arrived with particular strength for Tabasco in the mid-seventies. In this decade, the state of Tabasco became the top beef producer for Mexico City, which signified an increase in pastureland through the occupation of lands with high evergreen rainforest cover (Tudela, 1992; Manjarrez-Muñoz, 2007). The consolidation of traditional extensive cattle farming contributed to the deterioration of more than $95 \%$ of the high evergreen rainforest in all of the Grijalva-Usumacinta watershed territory (Isaac-Márquez et al., 2005; Zavala and Castillo 2007; García-Morales et al., 2014).

During the eighties, the government of Tabasco developed the first studies to

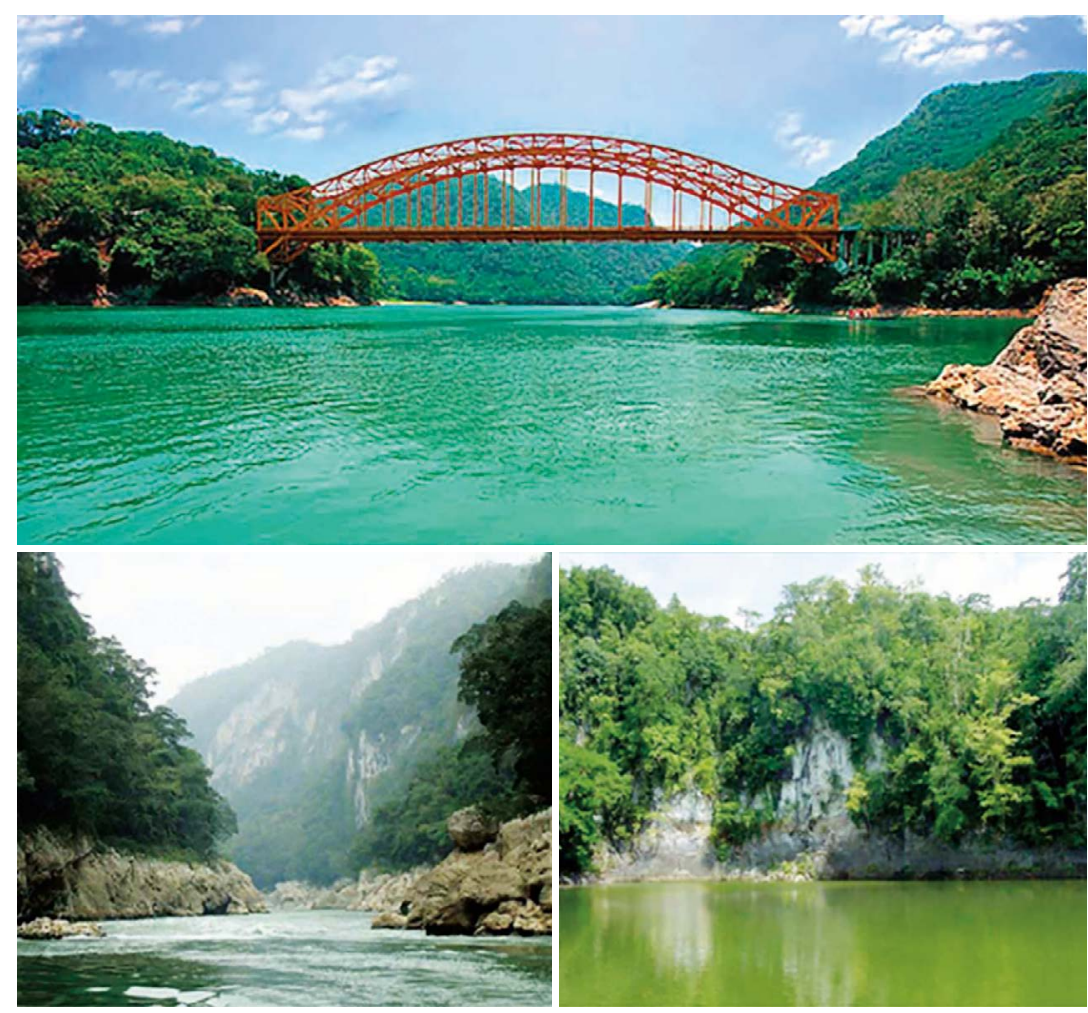

Figure 1. Rainforests and wetlands in the Usumacinta Canyon Flora and Fauna Protection Area, Mexico. Source: System of Public Research Centers CONACyT (2017). 
For this reason, the objective of this study was to evaluate the impact on natural vegetation as a result of livestock activities in the Usumacinta Canyon Flora and Fauna Protection Area, by analyzing the change in land use and vegetation in the periods between 1997-2009 and 2009-2016.

\section{MATERIALS AND METHODOLOGY}

\section{Study Area}

The Usumacinta Canyon Flora and Fauna Protection Area (Area de Protección de Fauna y Flora del Cañón del Sumidero, APFFCU) covers an area of 45,243 ha. The APFFCU is located between coordinates $17^{\circ} 14^{\prime} 00^{\prime \prime}$ and $17^{\circ}$

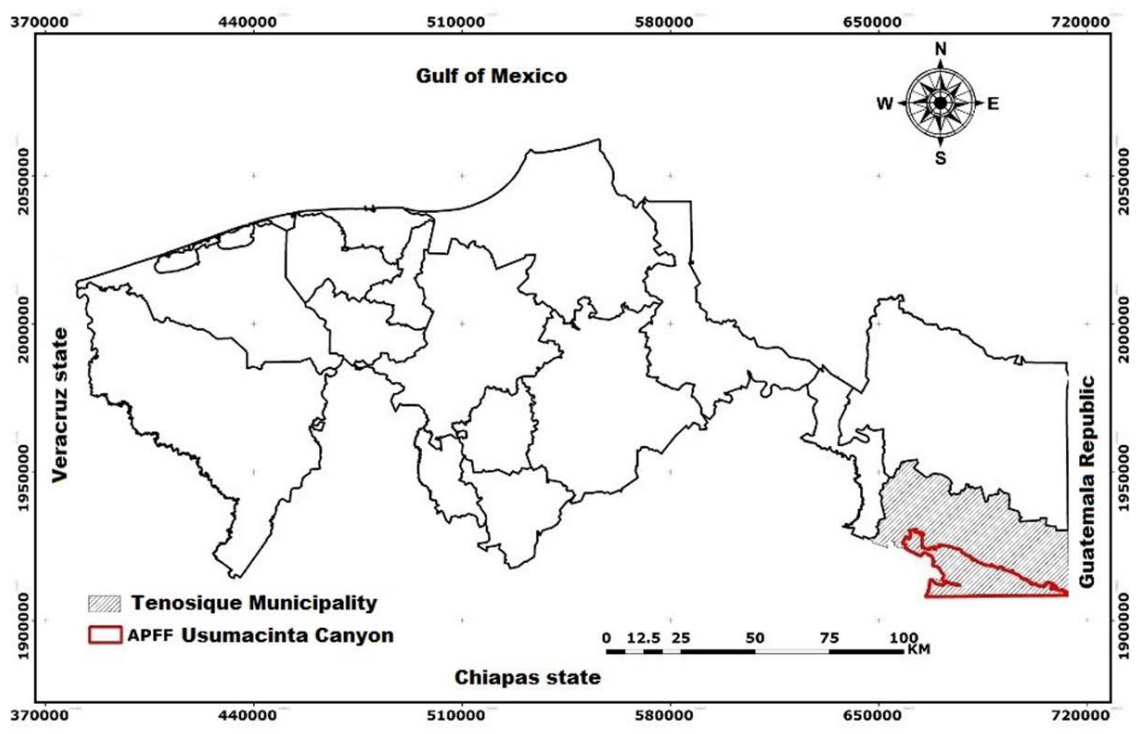

Figure 2. Geographic location of the Usumacinta Canyon Flora and Fauna Protection Area, Mexico. Source: self-made.

$28^{\prime} 00^{\prime \prime}$ North latitude, and $91^{\circ} 32^{\prime} 00^{\prime \prime}$ and $90^{\circ} 56^{\prime} 00^{\prime \prime}$ West longitude, in the southern part of the Tenosique municipality of Tabasco, bordering the Republic of Guatemala (Figure 2). It borders Chiapas to the west along the Usumacinta River for 33 kilometers; the Tenosique municipality to the north; and it borders Guatemala to the south in what is known as the physiographic province of the Sierra Madre de Chiapas and Guatemala, a sub-province of the El Petén lowlands (SEMARNAT, 2015). The predominant climate is warmhumid with year-round rain, and the average annual temperature is $26^{\circ} \mathrm{C}$ with a precipitation range of 1,500 to $2,500 \mathrm{~mm}$ annually (INEGI, 2015).

\section{Database Procurement}

Three shapefiles of vegetation and land use were downloaded at 1:250,000 scale (national continuum), corresponding to 1997 (series I), 2009 (series IV), and 2016 (series VI). The three shapefiles were obtained from the CONABIO geographic metadata catalogue with the geographic coordinate reference system UTM Zone 15 $\mathrm{N}$, using the DATUM WGS84 parameters.

The shapefiles were converted to raster format with a size of 10 meters per pixel, with 7280 columns and 7541 rows, using the RASTERVECTOR command of the IDRISI Terrset software. Later, they were reclassified using the RECLASS command of the IDRISI Terrset software with the following categories: (1) rainforest, (2) secondary vegetation, (3) wetland, (4) farmland, (5) pastureland, and (6) urban (Figure 3).

\section{Analysis of Changes 1997-2009-2016}

With the Land Change Modeler module of the IDRISI Terrset software, a change matrix was generated with raster images that varied in the number of study dates; that is to say, in more than two periods of time (Pontius et al., 2004). In this analysis, cross-referencing of the raster images from 1997 and 2009 generated a matrix with a statistical $\kappa=0.6444$, while the images from 2009 and 2016 generated a matrix with a statistical $\kappa=0.9088$. These statistics that are close to 1.000 are reliable for the study of the spatial and temporal dynamics of the ecosystems in two time periods (Eastman, 2012).

\section{Calculation of Change Rate}

The change rates were calculated using the PalacioPrieto et al. (2004) formula:

$$
T d=[(S 2 / S 1)(1 / n)-1] * 100
$$

where: $T d=$ annual change rate (\%), $S 1=$ Covered area at start of period (ha), $\$ 2=$ Covered area at end of period (ha), and $n=$ Number of years in period.

\section{RESULTS AND DISCUSSION \\ Change in Land Use 1997-2009}

During 1997 to 2009, losses of 21,870 ha of rainforest were detected, with a negative change rate of $7.4 \%$ (Table 1). This is very high compared to the deforestation rate at the regional level (0.90\%) during 1993 and 2007 in the Grijalva-Usumacinta watershed (Kolb and Galicia, 2012). 

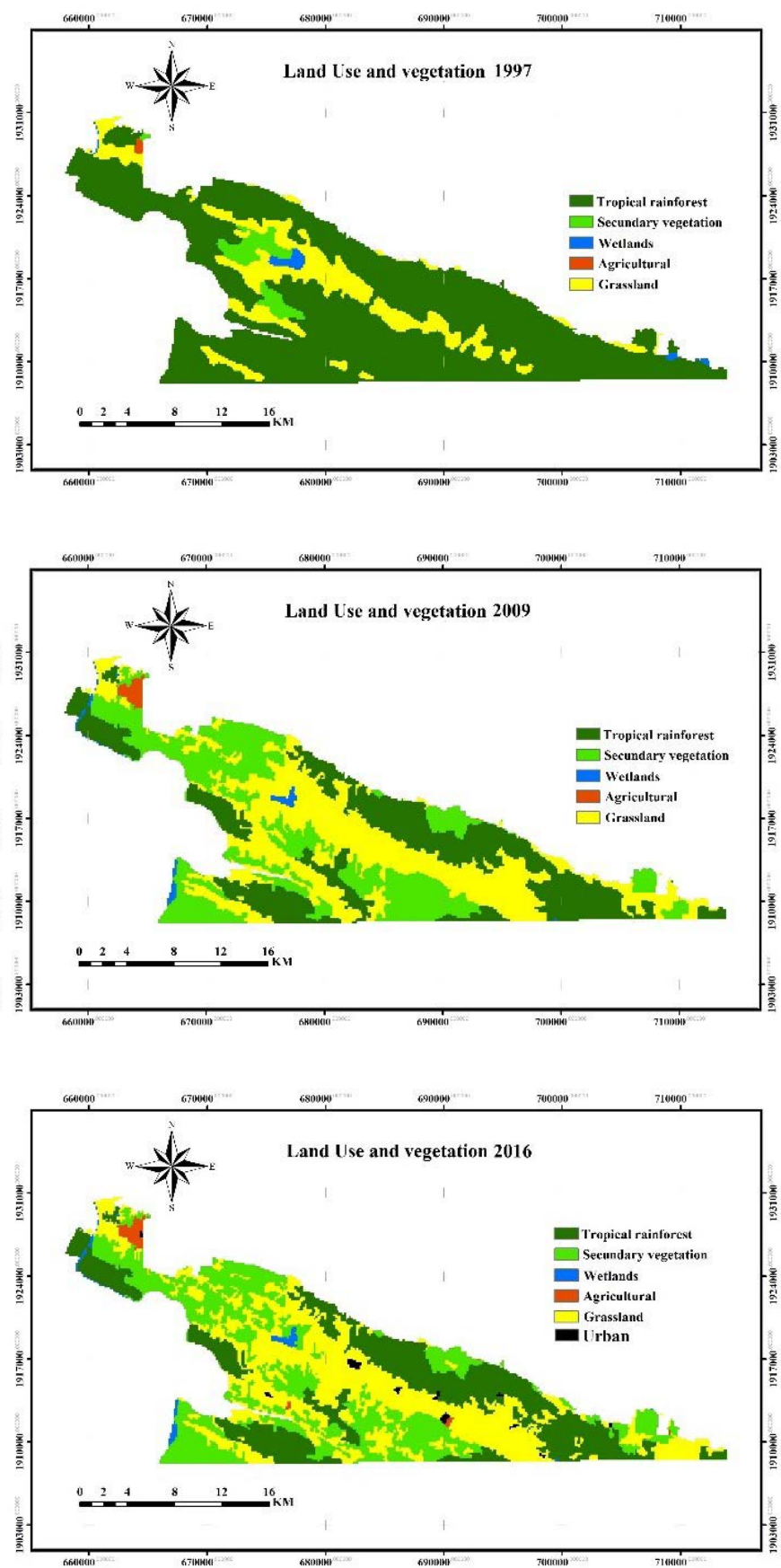

Figure 3. Maps of land use and vegetation 1997a, 2009b and 2016c in the Usumacinta Canyon Flora and Fauna Protection Area, Mexico. Source: self-made.
Even though Tabasco is not a completely cattle-farming state, it sends large amounts of fattened livestock to the north of Mexico. Thus, cattle farming and agriculture are the dominant activities in the rural setting, both with a high degree of environmental deterioration. In the case at hand, deforestation of the high evergreen forest begins with the establishment of maize (Zea mays) plots that make up a significant part of the country's diet, and which are then transformed into pastureland (GalindoAlcántara et al., 2006, Mifsut and Castro, 2010; VelascoTapia, 2010). The environmental impact generated by these farming systems is high; for cattle farming, because it is based on the transformation of natural vegetation with extensive grazing practices in pastures with low rates of summer pasture; and for agriculture, because the old slash-and-burn system continues to be maintained (Galindo-Alcantara, 1999).

The above shows that deforestation of the rainforest is not solely connected to population growth, but also to farming activities and external uses (Velasco-Tapia, 2010; Gallardo-Cruz et al., 2019).

At the start of the new century, deforested areas were rising due to the creation of programs supporting livestock ranches, such as PROGAN. This program aided 2,126 projects in Balancán and Tenosique between 2003 and 2005. In contrast, the program for rainforest restoration (PRODEFOR) only benefitted between 17 and 28 projects during 2004 and 2005 (Manjarrez-Muñoz et al., 2007). Notably, during 2000-2012, the municipality of Tenosique supplied between 20 and $40 \%$ of the total hectares of lost tree vegetation per year in the lower Usumacinta watershed (Gallardo-Cruz et al., 2019).

Conversely, the areas of succession or secondary vegetation (acahuales) increased by 13,682 ha, with a growth rate of $19.5 \%$ (Table 1). This increase is generally the result of a recovery process within abandoned

\begin{tabular}{|c|c|c|c|c|c|c|c|c|}
\hline Category & 1997 & $\%$ & 2009 & $\%$ & Losses & Gains & Net change & Exchange rate \\
\hline Tropical Rain forest & 35,696 & 78.9 & 14,121 & 31.2 & $-21,870$ & 295 & $-21,575$ & -7.4 \\
\hline Wetlands & 416 & 0.9 & 419 & 0.9 & -268 & 270 & 2 & 0.0 \\
\hline Agricultural & 81 & 0.2 & 374 & 0.8 & 0 & 293 & 293 & 13.6 \\
\hline
\end{tabular}


farming and pasture zones due to loss in soil fertility in the case of farmland, or to meat market prices that push farmers to sell their animals (Galindo-Alcántara et al., 2006).

\section{Change in Land Use 2009-2016}

In the 2009-2016 period, rainforests showed losses of $1,163 \mathrm{ha}$, therefore the negative change rate was at $0.8 \%$, less than that registered during 1997-2009 (Table 2). This decrease in the rate of deforestation is attributed to the high evergreen rainforest and fragmented rainforest having undergone reversal processes in their vegetation cover (Arreola-Muñoz et al., 2011). In Tabasco, the reversal of tree vegetation has occurred naturally and induced: naturally as a result of abandoned farming activities, and induced due to the growth in the number of reforestation programs for forestry activities and payment for ecosystem services (Alejandro-Montiel et al., 2010; Gallardo-Cruz et al., 2019). Particularly, the conservation of high evergreen rainforest during 20092016 coincides with the decree of the Usumacinta Canyon as a Federally Protected Area in 2008 (DOF, 2008).

Currently, the federal program Sembrando Vida ("Planting Life") could be a catalyst for environmental conservation, as it is driving agroforestry projects and Tabasco is one of the benefitted states (De la Barrera et al., 2019, Secretaría de Bienestar, 2020).

During the 2000 to 2016 period, the lower basin of the Usumacinta River has been the region with the lowest rainforest deforestation rates, compared to the middle and higher region. This condition could be influenced by the extension of the protected areas in the middle and lower basin. For example, the extension of Montes Azules is much greater than the area of the Usumacinta Canyon, so that by volume the area lost in the former is greater than in the latter (DOF, 2008; Gallardo-Cruz et al., 2019).
During 2009-2016, the deforestation rate notably decreased. Despite this, farming activities in the APFFCU continue to be unsustainable because they are organized in a traditional extensive farming system that combines agriculture and cattle ranching with low economic reinvestment and high use of local natural resources, resulting in significant pressure on the high evergreen rainforest (Nuncio et al., 2001). However, there are currently other strategies that are contributing to the reforestation of these spaces. Such is the case with the Sembrando Vida program, which fosters recovery through the introduction of timber-yielding and fruit trees to the natural forests that include recently abandoned parcels (De la Barrera et al., 2019).

To restore and conserve the last remnants of high evergreen rainforest and control the impact of farming activities, proposals have been elaborated with a focus on land zoning that consider at least two premises: the incorporation of tree cover into cattle ranching surface areas using silvopastoral systems, and the use of species and technologies in the cattle farming units that decrease the use of natural resources (Manjarrez-Muños et al., 2007). Also available is an ecological zoning model where land use designation is based on the condition and vocation of the natural resources, and which integrates socioeconomic, productive, environmental, legal, and administrative aspects in order to face existing environmental conflicts and induce the integral management of the Usumacinta Canyon, organized in Environmental Management Units (Unidades de Gestión Ambiental, UGA) (Arreola-Muños et al., 2011) (Table 3).

Among other actions, implementing monitoring of the principal patterns in land use and vegetation change is recommended, by way of current remote sensing techniques and Geographic Information Systems, in order to identify the chief conditioning factors of these impacts and to map future scenarios. Studies measuring ecosystem services are also important, with the objective

\begin{tabular}{|c|c|c|c|c|c|c|c|c|}
\hline Category & 2009 & $\%$ & 2016 & $\%$ & Losses & Gains & Net change & Exchange rate \\
\hline Tropical rainforest & 14121 & 31.2 & 13322 & 29.4 & -1163 & 365 & -799.0 & -0.8 \\
\hline Wetlands & 419 & 0.9 & 420.8 & 0.93 & -11 & 14 & 2.0 & 0.1 \\
\hline Agricultural & 374 & 0.8 & 432 & 0.95 & -16 & 74 & 59.0 & 2.1 \\
\hline
\end{tabular}


Table 3. Environmental Management Units (UGA) for the Usumacinta Canyon Flora and Fauna Protection Area, Mexico.

Land use

area (ha)

\begin{tabular}{l|c} 
Rural human settlements & 963,79 \\
\hline Rainfed agriculture & 445,14 \\
\hline Fruit tree & 83,28 \\
\hline Holistic Semi-Intensive Livestock & $7.750,21$ \\
\hline Plantaciones Forestales & $7.364,10$ \\
\hline Productive restoration & $1.654,33$ \\
\hline Agroforestry systems & $1.362,76$ \\
\hline Silvopastoral System & $9.790,17$ \\
\hline Environmental Rehabilitation & $14.232,16$ \\
\hline Ecoturism & 360,3 \\
\hline Xate and Motusay plantations & 11,04 \\
\hline Research work & $11.966,89$ \\
\hline
\end{tabular}

Source: Arreola-Muñoz et al. (2011).

of avoiding or reverting disturbance and conserving the original remains of the high rainforest, soil, and natural water flows that all maximize the provision of ecosystem services, since it is recognized that the Usumacinta rainforests are carbon sinks with relevance in America (Mifsut and Castro, 2010).

\section{CONCLUSIONS}

The study of the state of conservation in the high evergreen rainforest of the Usumacinta Canyon Flora and Fauna Protection Area determined that between 1997 and 2016, a total of 23,033 ha of rainforest were lost. Notably, the greatest negative change rate of rainforest was recorded in the period from 1997 to 2009 , which it decreased in 2016 possibly as a result of the decree of the Protected Area and the implementation of programs driving ecological restoration. Since the decrease in natural cover entails the loss of other organisms from habitat loss, including silvopastoral systems in farming units is recommended, as well as the use of new technologies that lower the use of natural resources. Even the Sembrando Vida program could play a fundamental role in the development and conservation of the area. In addition, execution and follow-up of the policies established in the land zoning model is recommended, as well as the promotion of permanent monitoring of changes in land use and of ecosystem services.

\section{REFERENCES}

Alejandro-Montiel, C., Galmiche-Tejeda, Á., Domínguez-Domínguez, M., \& Rincón-Ramírez, A. (2010). Cambios en la cubierta forestal del área ecoturística de la Reserva ecológica de Agua
Selva, México. Tropical and Subtropical Agroecosystems 12 (3) 605-617

Arreola-Muñoz, A., Reyes-Barrón, M.C., Segura-Bertollini, E.C., HernándezZárate, L.O., \& Llergo-Juárez, J.G. (2011). Ordenamiento Territorial de la Microrregión Cañón del Usumacinta, Municipio de Tenosique, Tabasco. Villahermosa, México: SERNAPAM

Arriaga, L.J., Espinoza, J.C., Aguilar, C., \& Martínez, E. (2000). Regiones terrestres prioritarias de México. Ciudad de México: CONABIO.

De la Barrera, P. (2012). Los servicios ecosistémicos que ofrecen los bosques tropicales. Revista Ecosistemas, 21(1-2): 136-147.

De la Barrera, E., Villalvazo-Figueroa, E.A., Díaz-Álvarez E. A. et al. (2019) 4T don't stand for tacos: An analysis of food and environmental security considerations in the new Mexican government's agricultural agenda. Food Research 8:1768

Diario Oficial de la Federación. (2008). Decreto por el que se declara área natural protegida con la categoría de área de protección de flora y fauna, la región conocida como Cañón del Usumacinta, localizada en el Municipio de Tenosique, en el Estado de Tabasco. Ciudad de México: Congreso de la Unión

Eastman, J.R. 2012. IDRISI Selva GIS and image processing software version 17.0. Clark Labs. Massachusetts., USA. $321 \mathrm{p}$

Gallardo-Cruz, A., Fernández-Montes de Oca, A., \& Rives, C. (2019) Detección de amenazas y oportunidades para la conservación en la cuenca baja del Usumacinta a partir de técnicas de percepción remota. Revista Ecosistemas 28 (2): 82-99. doi 10.7818/ECOS.1611

Galindo-Alcántara, A., Gama-Campillo, L. M., Ruiz-Acosta, S., \& MoralesHernández, A. (2006). Programa de conservación y manejo del Parque Estatal Cañón del Usumacinta. Villahermosa, México SEDESPA

García-Morales, R., Gordillo-Chávez, E. J., Valdez-Leal, J. D. D. y Pacheco-Figueroa, C. (2014). Las áreas naturales protegidas y su papel en la conservación de los murciélagos del estado de Tabasco, México. Therya 5(3): 725-736

García, G. D., \& Soares, D. (2017). Introducción. En D. Soares y A. García (Eds.), En La cuenca del río Usumacinta desde la perspectiva del cambio climático. Ciudad de México: CONACYT-SEMARNATIMTA

Hernández-López, A., López-Alamilla, E., Ramírez, A. R., \& AquinoBravata, V. (2013). Diagnóstico del uso de la fauna silvestre, en el área de protección de flora y fauna. Ra Ximhai 9 (1): 1-14

Instituto Nacional de Estadística, Geografía e Informática (INEGI). (2015). Prontuario de información geográfica municipal de los Estados Unidos Mexicanos. Tenosique, Tenosique, Tabasco. Clave geoestadística 27017. INEGI. México.

Isaac-Márquez, R., De-Jong, B., Eastmond, A., Ochoa-Gaona, S. Hernández, S., \& Kantún, M.D. (2005). Estrategias productivas campesinas: un análisis de los factores condicionantes del uso del suelo en el oriente de Tabasco, México. Universidad y Ciencia 21(42): 57-73

Jiménez-Sierra, C.L., Sosa-Ramírez, J., Cortés-Calva, P., BrecedaSolia, C.A., Îñiguez Dávalos, L.I., \& Ortega-Rubio, A. (2014) México país megadiverso y la relevancia de las áreas naturales protegidas. Investigación y Ciencia 22 (60): 16-22.

Kolb, M., \& Galicia, L. (2012). Challenging the linear forestation narrative in the Neo-tropic: regional patterns and processes of deforestation and regeneration in southern Mexico. The Geographical Journal 178 (2): 147-161 
Manjarrez-Muñoz, B., Hernández-Daumás, S., De-Jong, B., Nahed-Toral, J., Dios-Vallejo, O. O. D., \& SalvatierraZaba, E. B. (2007). Configuración territorial y perspectivas de ordenamiento de la ganadería bovina en los municipios de Balancán y Tenosique, Tabasco. Investigaciones Geográficas (64): 90-115.

Mifsut, I. M., \& Castro, M. (2010). La cuenca del Río Usumacinta: perfil y perspectivas para su conservación y desarrollo sustentable. Las cuencas hidrográficas de México. Diagnóstico y priorización. Ciudad de México: SEMARNAT

Nuncio-Ochoa, G., Nahed-Toral, J., Díaz-Hernández, B., Escobedo-Amezcua, F. \& Salvatierra-lzaba, B. (2001). Caracterización de los sistemas de producción ovina en el estado de Tabasco. Agrociencia 35(4): 469477.

Palacio-Prieto, J.L., Sánchez-Salazar, M.T., Casado, J.M., Propin, F.E., Delgado, C.J., Velázquez, M.A., \& Camacho, R.C.G. (2004). Indicadores para la caracterización y el ordenamiento territorial. Ciudad de México: SEMARNAT.

Palomeque de la Cruz, M. Á. (2008). Análisis del cambio de uso del suelo y las actividades productivas en el parque estatal Cañón del Usumacinta en Tenosique, Tabasco. Tesis de Maestría en Ciencias Ambientales. División Académica de Ciencias Biológicas, Universidad Juárez Autónoma de Tabasco. Villahermosa, México.

Periódico Oficial del Estado de Tabasco. (2005). Decreto por el cual se declara Área Natural Protegida de Carácter estatal, el Parque Estatal Cañón del Usumacinta Tenosique Tabasco. Villahermosa, México: Oficialía Mayor de Gobierno.

Pontius J., R.G., Huffaker, D., \& Denman, K. (2004). Useful techniques of validation for spatially explicit landchange models. Ecological Modelling 179(4): 445-461.

Rzedowski, J., \& Huerta, L. (1994). Vegetación de México. Ciudad de México: Limusa, Noriega Editores.

Sistema de Centros Públicos de Investigación CONACYT (2017). Explorando el Usumacinta. Conociendo Tenosique. Recuperado de https://centrosconacyt.mx/objeto/usumacinta/

Secretaría de Medio Ambiente y Recursos Naturales (SEMARNAT). (2015). Programa de Manejo Área de Protección de Flora y Fauna Cañón del Usumacinta. Ciudad de México: SEMARNAT-CONANP

Tudela, F. (1992). La modernización forzada del trópico: el caso de Tabasco. Ciudad de México: El Colegio de México

Velasco-Tapia (2010). Identificación de cambios en el uso del suelo y vegetación, y cálculo de la tasa de transformación del hábitat en el periodo 2000-2010, Área de Protección de Flora y Fauna Cañón del Usumacinta. Ciudad de México: CONANP

Zavala, J., \& Castillo, A. O. (2007). Cambio de uso de la tierra en el estado de Tabasco. En D. J. Palma y A. Triano (Eds.), Plan de uso sustentable de los suelos del estado de Tabasco (vol, II, pp. 38-56). Villahermosa, México: Colegio de Posgraduados.

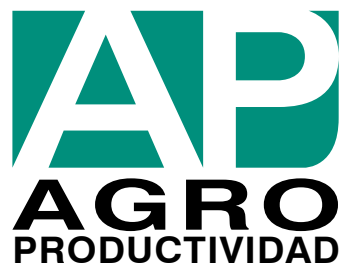

